\title{
ANALYSIS OF THE FLAME PULSATION SIGNALS USING A SHORT-TIME FOURIER TRANSFORM
}

\author{
Żaklin Grądz \\ Lublin University of Technology, Institute of Electronics and Information Technology
}

Abstract. The main aim of the diagnostics of combustion process is ensuring its stability and efficiency. The most important aspect related to the monitoring of the combustion process is a non-invasive acquisition of information from flame and subsequently subjecting it for further processing. Such method of research allows to evaluate the course of the process and determine the characteristic conditions under which the combustion process is stable or not. The article presents the application of short-time Fourier transform for the analysis of flame pulsation signals. The aim of the research was to find an area especially sensitive to the change of combustion process conditions.

Keywords: combustion process, short-time Fourier transform, flame pulsation

\section{ANALIZA SYGNALÓW PULSACJI PLOMIENIA Z WYKORZYSTANIEM KRÓTKOCZASOWEJ TRANSFORMATY FOURIERA}

Streszczenie. Głównym celem stawianym diagnostyce procesu spalania jest zapewnienie stabilności i efektywności przebiegu procesu. Najważniejszym aspektem monitorowania procesu spalania jest pozyskiwanie $w$ sposób bezinwazyjny informacji z płomienia, a następnie poddanie jej dalszemu przetwarzaniu. Taki sposób badań pozwala na ocenę przebiegu procesu i daje możliwość wyznaczania charakterystycznych stanów, w których proces przebiega stabilnie lub nie. W artykule przedstawiono wykorzystanie krótkoczasowej transformaty Fouriera do analizy sygnałów pulsacji płomienia. Celem badań było znalezienie obszaru szczególnie wrażliwego na zmianę warunków w procesie spalania.

Słowa kluczowe: proces spalania, krótkoczasowa transformata Fouriera, pulsacja płomienia

\section{Introduction}

The recent regulations implemented due to the need for reduction of the emission of harmful gases into the atmosphere, including nitrogen oxides (NOx) led to the popularization of socalled low-emission combustion techniques. In most cases, they involve the application of the combustion technology with air stepping, which is based on the formation of zones in the flame, in which combustion occurs with varying stoichiometry $[3,5,7,13]$. Zonal combustion is a process in which maintaining the process conditions within specific limits is especially important, in contrast to traditional combustion. Therefore, the application of monitoring systems is necessary. Therefore, monitoring and diagnostics of the combustion process are still a valid and relevant issue of modern energy economics.

Combustion of coal dust under industrial conditions is a complex process, which requires the application of specialized measurement systems for diagnostics. A combustion process is considered efficient when the combustion is stable and emission of resulting pollutants conforms to the valid standards. The generated harmful combustion products include the ones that arise from the burning of elemental coal and hydrocarbons in the case of [5]:

- complete combustion of elemental coal $-\mathrm{CO}_{2}$,

- incomplete combustion of coal and hydrocarbons - CO,

aldehydes, polycyclic aromatic hydrocarbons and soot.

Within the group of combustion by-products, which arise from the presence of fuel additives, one should also distinguish SOx, NOx and ash [3]. In order to mitigate the emission of hazardous compounds, the primary and secondary methods are commonly used. The primary methods are employed directly in the combustion chamber and involve preventing the creation or reducing the undesirable combustion products. Low-emission combustion is an example of a primary method. On the other hand, the secondary methods are applied outside the combustion chamber and their aim is to eliminate the harmful substances using catalytic reduction and absorption methods [5].

The signals acquired from the flame monitoring system are non-periodic. Therefore, short-time Fourier transform can be applied for their analysis and processing.

\section{Analysis of the coal pulverized combustion process}

Acquisition of the data pertaining to the combustion process which occurs under the industrial conditions requires the application of specialized measurement systems [1, 2, 6, 15]. Flame monitoring system devised in Institute of Electronics and Information Technology of the Lublin University of Technology is an example of such a system [14]. The system, used for obtaining the measurement data from a flame is capable of conducting noninvasive measurements in real-time. Figure 1 presented below shows the scheme of the considered flame monitoring system.

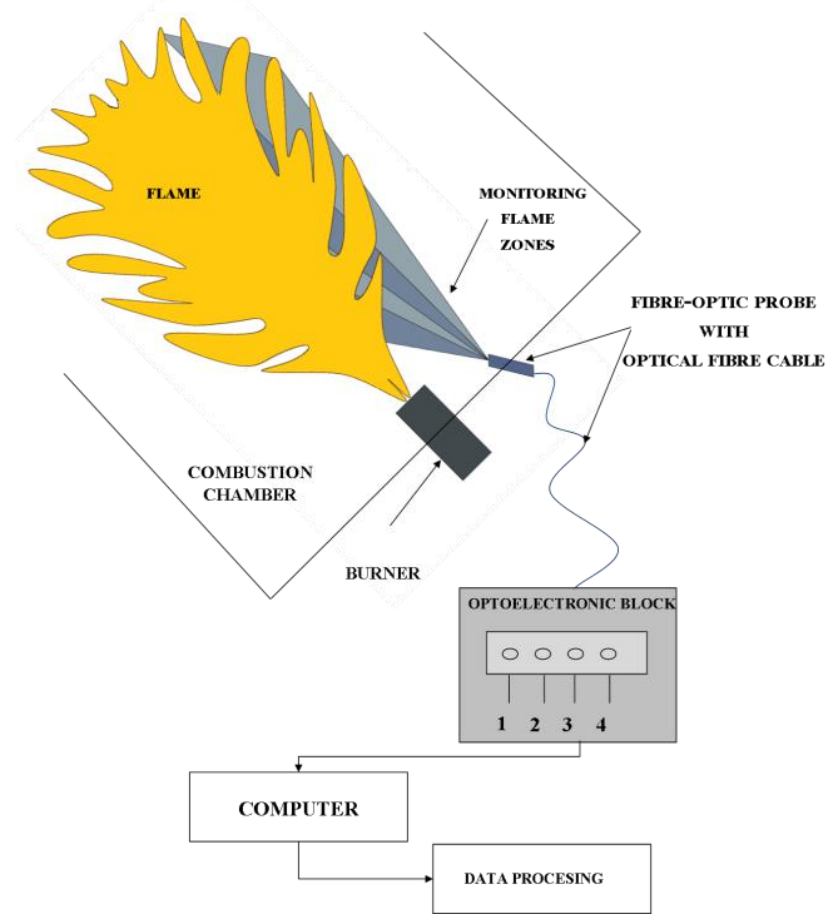

Fig. 1. Flame monitoring system 
The flame monitoring system comprises: a measurement probe, photodetectors, and an optoelectronic block. In order to conduct measurements, the head of optical fibre probe is mounted through the hole inside the combustion chamber. The information on the combustion process obtained from the flame is transmitted by means of the measurement head and optical fibre bundles to the optoelectronic block in the form of an optical signal. The optoelectronic block is composed of four identical signal channels. The channels 1-4 enable monitoring of different flame zones, which was presented in Fig. 1.

The design of the probe used for research enables conducting measurements under the conditions characterized by high temperature and dusting. During the measurements, the flame luminosity and pulsation are recorded. Flame luminosity is the parameter that determines the temperature of flame, whereas pulsation is a measure of flame turbulence [12]. In the optoelectronic block, the data are transformed into an electric signal which is subjected to further processing.

\section{Frequency analysis of the signal}

The analysis of the signals obtained from the combustion process occurring in energy boilers may be conducted in a number of ways. One of them involves the frequency analysis, which may be carried out using the Fourier transform. Discrete Fourier transform is expressed by the formula [10]:

$$
X(k)=\sum_{n=0}^{N-1} x(n) W_{N}^{k n}
$$

where $k=0,1,2, \ldots, N-1$ and $W_{N}=\mathrm{e}^{-j 2 \pi / N}$

Processing signals using Fourier transform may be carried out using Matlab software, which is employed for the calculation of the fast Fourier Transform FFT that is realized by the fft function [9]. The correct result of the Fourier analysis of the signal sampled with the frequency $f_{s}$ is possible only when the distribution of harmonics in the range of positive frequencies does not interfere with the range of negative frequencies [10]. This occurs when the highest frequency in the signal does not exceed the Nyquist frequency [10].

The frequency analysis is conducted while processing the discrete signal $\mathrm{x}(\mathrm{n})$, in accordance with the following steps [16]:

- low-pass filtration,

- discretization in time, quatization and coding,

- multiplication of the signal with time window,

- indication of the discrete Fourier transform.

The parameters and equations of several selected discrete windows $w(n)$, which are applied during the frequency analysis, were provided below. Using any function of the window $w(n)$, a fragment of the signal subjected to analysis is cropped. The time windows require multiplication of subsequent signal samples with the samples of time windows. These windows assume non-zero values only for $n=0,1,2, \ldots, N-1$, where $N$ corresponds to any length of the windows [16] and are determined in the following way [16]:

- Bartlett (triangular) window - width of the main lobe $\Delta m l=8 \pi / N$, relative suppression of the highest side lobe $A_{s l}=26.5 \mathrm{~dB}$, definition:

$$
1-\frac{2|n-(N-1) / 2| \mid}{N-1}
$$

- Hanning window - width of the main lobe $\Delta m l=8 \pi / \mathrm{N}$, relative suppression of the highest side lobe $A_{s l}=31.5 \mathrm{~dB}$, definition:

$$
\frac{1}{2}\left(1-\cos \left(\frac{2 \pi n}{N-1}\right)\right)
$$

- Hamming window - width of the main lobe $\Delta m l=8 \pi / \mathrm{N}$, relative suppression of the highest side lobe $A_{s l}=42.7 \mathrm{~dB}$, definition:

$$
0,54-0,46 \cos \left(\frac{2 \pi n}{N-1}\right)
$$

- Blackman window - width of the main lobe $\Delta m l=12 \pi / \mathrm{N}$, relative suppression of the highest side lobe $A_{s l}=58.1 \mathrm{~dB}$, definition:

$$
0,42-0,50 \cos \left(\frac{2 \pi n}{N-1}\right)+0,08 \cos \left(\frac{4 \pi n}{N-1}\right)
$$

The definition of window $w(n)$ shows the dependence of $0 \leq n \leq N-1$.

Matlab software includes numerous defined functions of windows, such as rectangular window, Blackman window, Hamming window, Hanning window, and Bartlett window. The figure presents examples of the window functions $[10,16]$.

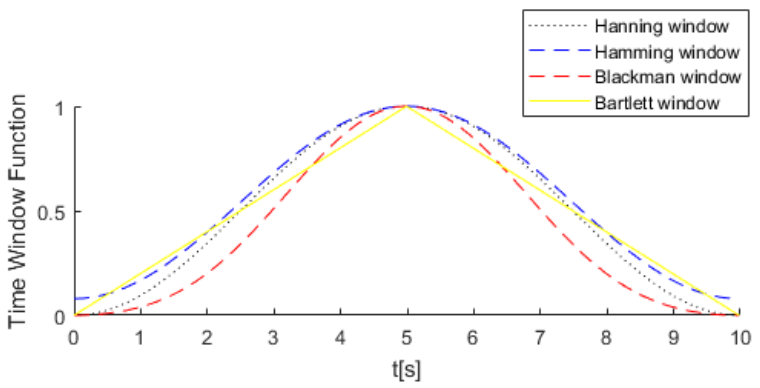

Fig. 2. Shape of the function of Hamming Hanning, Blackman and Bartlett windows

\section{Analysis of the measurement data}

The measurement data were acquired using the aforementioned combustion process monitoring system. One of the parameters recorded in the course of the flame measurements involved its luminosity. Figure 3 presents the first stage of data analysis, which included determining the flame luminosity within the measurement cycle from 4 different channels of the optical fibre probe.

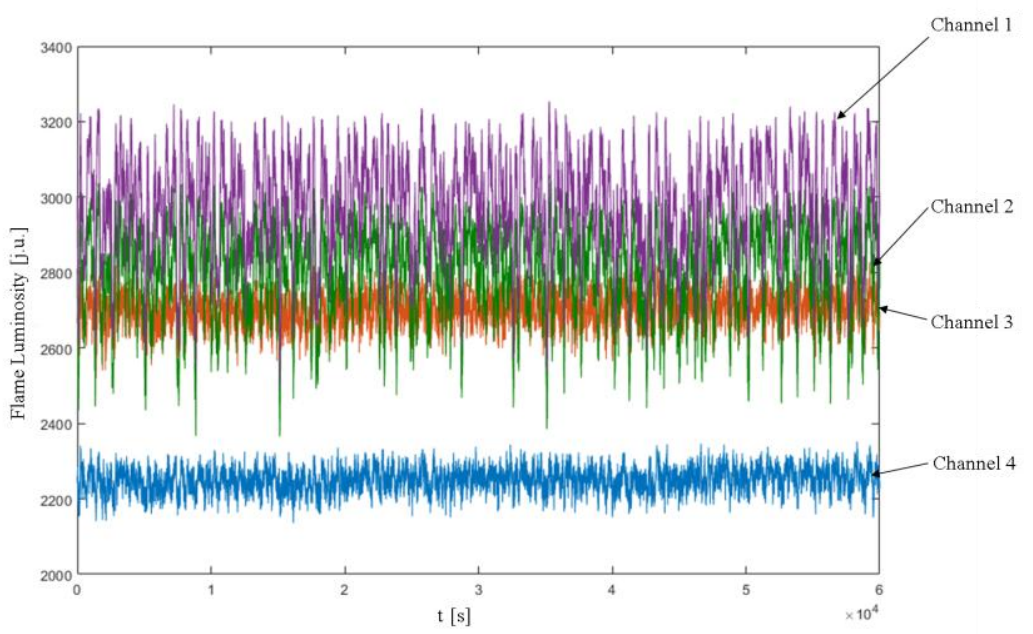


Due to the large amount of measurement data, conducting the analysis for an entire signal acquired from a single channel of the optical fibre probe yields little information. Therefore, it is necessary to perform separate analyses for each of the signals. The conditions that influence the flame luminosity or its pulsation include, i.a. changes in the air flow rate, inclusion/exclusion of mazut or changes in fuel supply. The conditions prevailing in the combustion chamber and the composition of the fuel burn have a significant impact on the stability of the combustion process. Separation of particular stable and unstable areas will enable to obtain detailed information on the investigated process.

The next step of result preparation involved processing of selected areas using windowed Fourier transform [4]. The data were subjected to analysis with selected types of time windows, using different lengths.

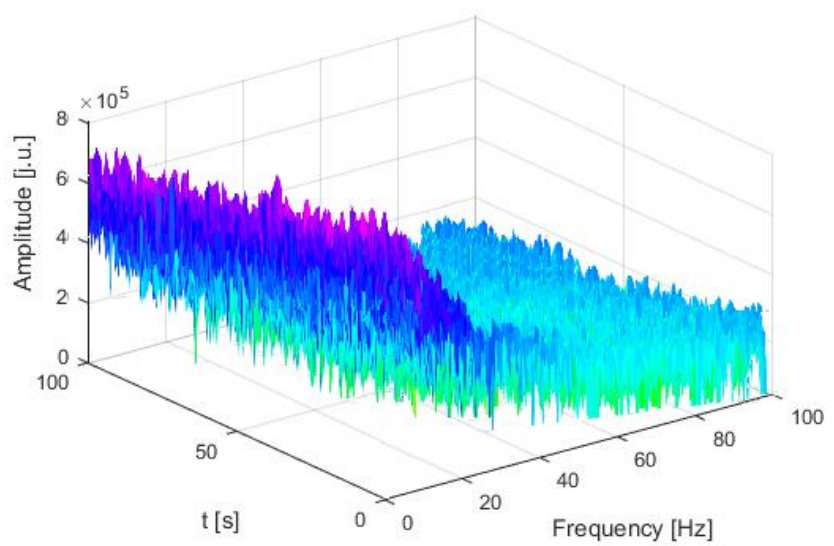

Fig. 5. Fourier Transform graph with Hamming window with the length of $N=128$ for the stable area I

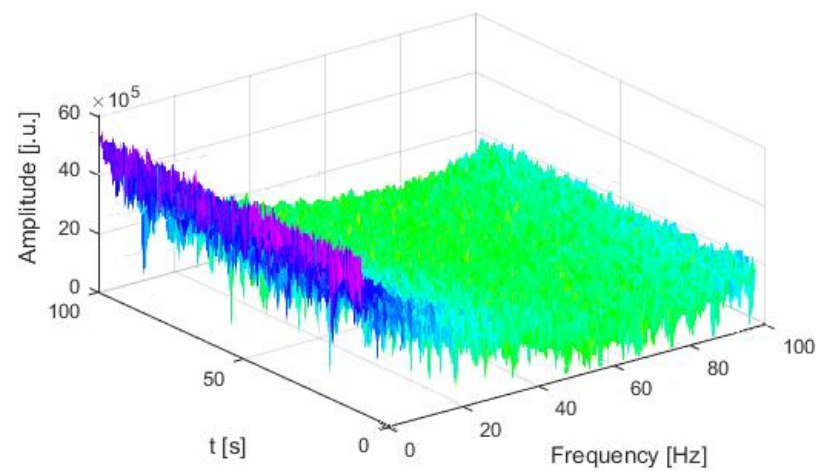

Fig. 6. Fourier Transform graph with Hamming window with the length of $N=1046$ for the unstable area I

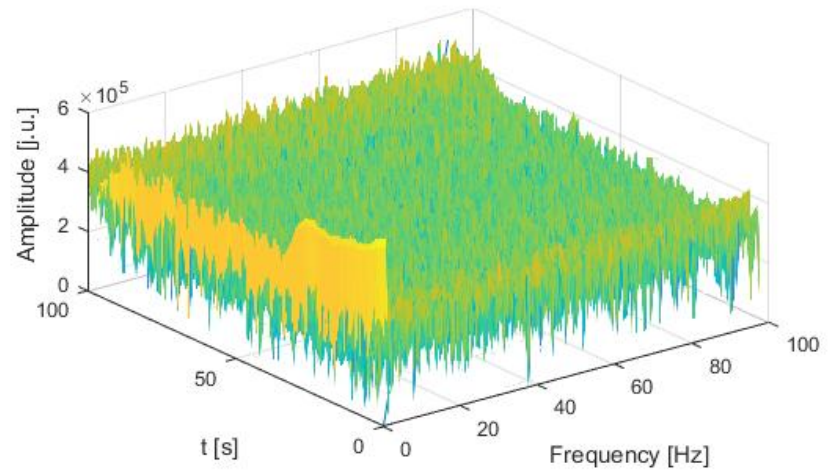

Fig. 7. Fourier Transform graph with Hamming window with the length of $N=128$ for the stable area I
The figures below present the graphs showing the stable area I for different window lengths: $N=128, N=1046$.

Figures 7, 8 show the graphs for the unstable area I with different window lengths: $\mathrm{N}=128, \mathrm{~N}=1046$.

The diagrams showed above were presented for the unstable area I and II and stable area I, which are especially vulnerable to the changes in the conditions of the combustion process. The graphs show the change in time of the flame pulsation frequency for the areas considered stable and unstable. Increasing the length of the time window is connected with and improvement in the localization of the frequency domain and deterioration in the time domain. On the basis of the analysis results it should be concluded that the stable area I is the most vulnerable.

The graphs showing the unstable area II for different window lengths: $\mathrm{N}=128, \mathrm{~N}=1046$ are presented in the Figures below.

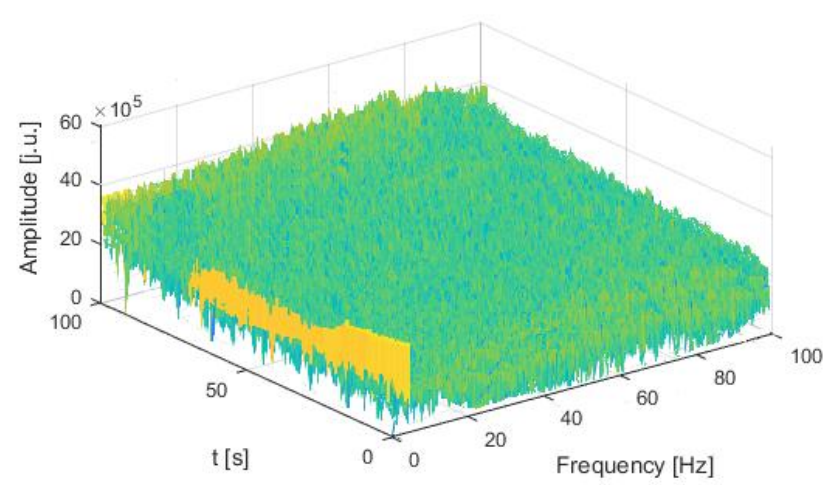

Fig. 8. Fourier Transform graph with Hamming window with the length of $N=1046$ for the stable area I

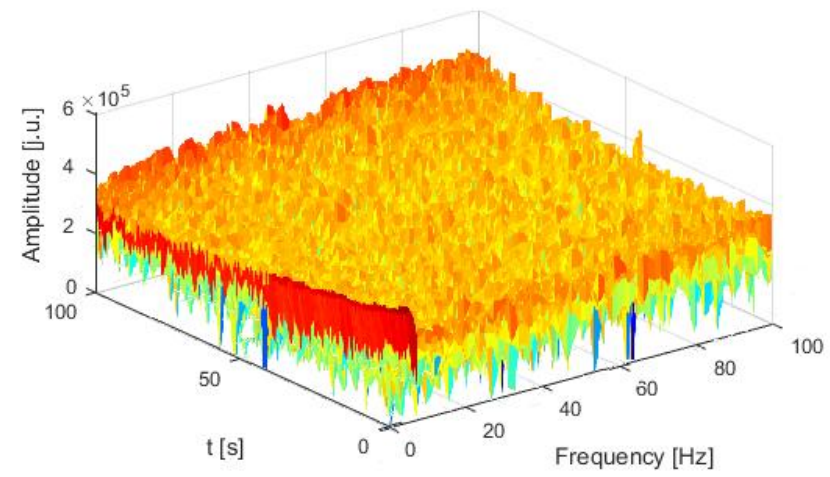

Fig. 9. Fourier Transform graph with Hamming window with the length of $N=128$ for the unstable area II

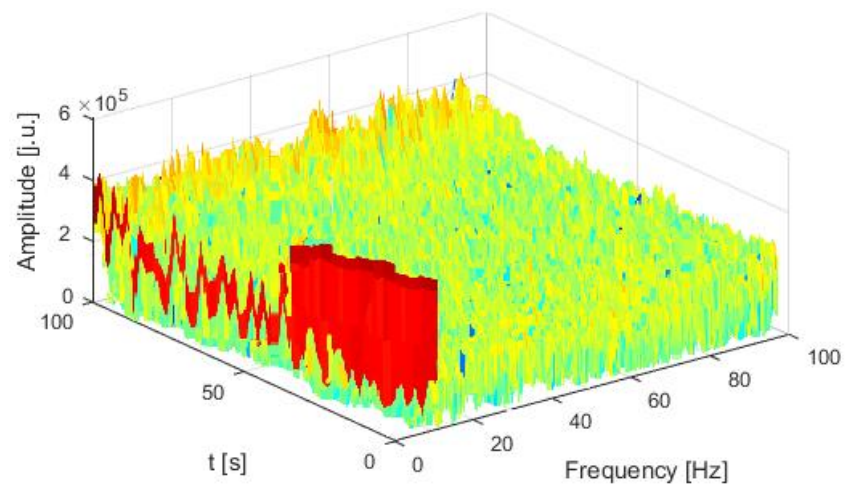

Fig. 10. Fourier Transform graph with Hamming window with the length of $N=1046$ for the unstable area II 


\section{Conclusion}

Combustion of coal dust under industrial conditions is a very complex process. Acquisition of data from a flame requires the application of specialized monitoring systems. The systems must be resistant to high temperatures and dusting. Their application yields huge amounts of data pertaining to the combustion process. The information obtained from the flame is transmitted in the optical form to the optoelectronic block, where it is transformed into electronic signal and may be subjected to further processing. The paper presented the analysis of measurement data for 3 different states of the process - unstable (I and II) and stable (I). Due to the fact that changing the type of window does not impact the Fourier transform, the article presents research conducted using the Hamming window. Changing the window size had an influence on indicating the signal frequency. Selecting a narrow window in the time domain causes the window in the frequency domain to become wide and vice-versa. While carrying out the Fourier transform in the time domain is could be seen that the window size has an influence on indicating the frequency of the investigated signal $[8,11]$.

\section{References}

[1] Ballester J., García-Armingol T.: Diagnostic techniques for the monitoring and control of practical flames. Progress in Energy and Combustion Science, 36(4)/2010, 375-411.

[2] Denisova N., Tretyakov P., Tupikin A.: Emission tomography in flame diagnostics. Combustion and Flame 160(3)/2013, 577-588.

[3] Guiberti T.F., Durox D., Schuller T.: Flame chemiluminescence from CO- and N-diluted laminar CH/air premixed flames. Combustion and Flame 181/2017, $110-122$.

[4] Kotyra A., Wójcik W.: Wykorzystanie deksryptorów Fouriera w diagnostyce procesu spalania. Pomiary Automatyka Kontrola 10/2010, 57-60.

[5] Kordylewski W.: Niskoemisyjne techniki spalania w energetyce. Wydawnictwo Politechnika Wrocławska, Wrocław 2000

[6] Krishnan P. H., Vinoth R.: Monitoring and controlling the combustion quality in thermal power plant boiler using image processing and robotic arm.
International Conference on Green Computing Communication and Electrica Engineering (ICGCCEE) 2014, 1-4.

[7] Li J., Yang W., Blasiak W., Ponzio A.: Volumetric combustion of biomass for CO2 and NOx reduction in coal-fired boilers. Fuel 102/2012, 624-633.

[8] Lijun X., Yong Y.: An Improved Algorithm for the Measurement of Flame Oscillation Frequency. Instrumentation and Measurement IEEE Transactions 56/2007, 2087-2093

[9] Matlab: Signal processing toolbox - User's Guide, Natick 2018

[10] Osowski S., Cichocki A., Siwek K.: Matlab w zastosowaniu do obliczen obwodowych i przetwarzania sygnałów. Oficyna Wydawnicza Politechniki Warszawskiej, Warszawa 2006

[11] Pilek B.: Analiza przydatności optoelektronicznych sygnałów pomiarowych płomienia do diagnostyki procesu spalania. Wydawnictwo Politechniki Lubelskiej, Lublin 2014.

[12] Smolarz A., Lytvynenko V., Kozhukhovskaya O., Gromaszek K.: Combined clonal negative selection algorithm for diagnostics of combustion in individual pc burner, Informatyka Automatyka Pomiary w Gospodarce i Ochronie Środowiska 4/2016, 77-80.

[13] Toporov D., Bocian P., Heil P., Kellermann A., Stadler H., Tschunko S., Kneer R.: Detailed investigation of a pulverized fuel swirl flame in $\mathrm{CO} 2 / \mathrm{O} 2$ atmosphere. Combustion and Flame 155(4), 2008, s. 605-618.

[14] Wojcik W.: Application of fibre-optic flame monitoring systems to diagnostics of combustion process in power boilers, Bulletin of the Polish Academy of Sciences - Technical Sciences 56(2)/2008, 177-195.

[15] Wojcik W., Kotyra A., Komada P., Golec T.: Fiber optic system detecting the type of burned fuel in power boilers. SPIE 5125, 2003.

[16] Zieliński T.P.: Cyfrowe przetwarzanie sygnałów: Od teorii do zastosowań Wydawnictwo Komunikacja i Łączność, Warszawa 2014

\section{M.Sc. Eng. Żaklin Grądz \\ e-mail: z.gradz@pollub.pl}

Assistant in the Institute of Electronics and Information Technology of Lublin University of Technology and Ph.D. student at the Electrical Engineering and Computer Science Faculty. Scientific activity includes the analysis of the combustion process in terms of its monitoring and diagnostics.

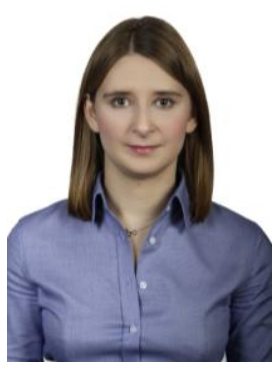

